\title{
Reversing the Gaze: Subversion and Re-interpretation of Mythical Stereotypes in Chitra Banerjee Divakaruni's The Palace of Illusions
}

\author{
Chayanika Roy \\ Assistant Professor of English \\ Mahadevananda Mahavidyalaya \\ Barrackpore, W. B. India
}

\begin{abstract}
Epics are indeed an indelible part of our existence carrying us into the timeless history where reality and fantasy blends into a harmonious whole. A diasporic women writer re-creating myth and folklore in a contemporary context and re-telling a popular epic Mahabharata from Draupadi's perspective is monumental and extraordinary. There have been sudden inclinations on part of the contemporary writers to re-interpret the epics in a new light highlighting the women characters who have been otherwise neglected in the original story as tangible subjects.
\end{abstract}

Usually, epic narratives portray women on an ideological viewpoint; women being embodiments of perseverance and forbearance, mute spectators of misery and injustice perpetrated on them. But Divakaruni re-created the women characters by assigning them a voice of their own so that they become strong enough to express their choices and by living their own bodies vis-à-vis lives. The mystifying feminine psyche of the mythical women characters is unfolded before the readers and many unknown crevices of the inner mind are laid bare. These impressions and explorations of the epic characters were actually a hidden trope for self-discovery and articulation. The Palace of Illusions is a re-creation of the illusionary, magical world of Draupadi and her dream destination and how this world gets shattered in front of her eyes is not only literal but metaphorical in course of the novel. In an attempt to re-work the epic, the contemporary women writers deviate from the usual phallocentric thrust of the epic and make Draupadi the hero of the novel; subverting the stereo-typed gendered version of an epic. Divakaruni's fiction strives to subvert the gendered 
binaries looking at the epic and its magnificent characters and events through Panchaali's gaze. Thus, the Western model of the male gaze is repudiated and the female gaze is celebrated in an altogether new form. Is the story of Mahabharata a familial clash between fraternity or a woman's personal desire and Panchaali's revenge which drenched the country and its inhabitants in the blood is the question that is left open-ended for the readers who revisits Mahabharata through the eyes of Draupadi vis-a-vis Chitra Banerjee Divakaruni.

Keywords: Male Gaze, Female Gaze, Epic, Myth, Gender, Self-Discovery, Subversion, Authority

The female gaze unlike the male gaze has different power dynamics and does not objectify men to be a subject of their desires and pleasures of looking. Desire, emanating from language gives the allowance for transcending the instinctual and the imaginary but its point of reference continuously reverts to the torturous moment of its birth. The women as an object of gaze are not significant in the narrative but as one who makes the male characters act the way they do. The female gaze that Divakaruni portrayed through the figure of Draupadi is not about pleasure or even power; it is about presence. Chitra Divakaruni penetrated through the heart of Panchaali and revealed many hidden secrets. Chitra Banerjee thought that Draupadi can be an ideal character for multiple interpretations rather than limiting her to one who was born to change history as per the divine intervention. Draupadi had that aura and authority in her character so as to enter the arena of male supremacy and question diplomatic and administrative affairs of the court. So, she could conveniently camouflage herself into the patriarchal sphere of regal life and become 'the hero' in the true sense. Divakaruni deconstructs to reconstruct her female characters that are usually pushed off to the sides, overlooked and ignored through the powerful, enigmatic, vibrant portrayal of Draupadi in The Palace of Illusions. Recently there has been an upsurge among contemporary women writers to pen down myth in a myriad fashion and one of the popular women writers of recent time is Kavita Kane whose books on mythology Lanka's Princess, Sita's Sister, Karna's wife: the Outcast Queen are remarkable and unnatural. Kane deals with sexually liberated women of mythology who have strived hard to substantiate their assertion and independence in the patriarchal paradigm. If in Ramayana, for Kane, Suparnakha 
challenged the illusion that women have to be subservient to men, in The Palace of Illusions Draupadi too questioned the autocracy of male society. When women speak out, become perceptible and take control of situations the illusion of male power is thwarted. Chitra's Draupadi is bold, upfront, a free-thinking character but somewhere she is shattered, disillusioned and mystic. Draupadi who emanated from fire ultimately consumes herself in the rage of fire fighting against injustices crowding in the kuru dynasty. She goes on to break several pre-conceived notions of women and rejects things that do not fuel the fire of her selfesteem. Draupadi has been alleged for the outbreak of the great war between Kauravas and Pandavas and the misdeeds of the kurus elude from history. The Palace of Illusions give Draupadi space and voice which she has been denied for ages and Divakurni gives her a different edge. Draupadi became the true scapegoat in the game of dice between two fraternities. She was disrobed in front of the scions of the Kuru dynasty and her questions which thwarted the pillars of the palace remain unanswered. The male gaze of the Kauravas and Karna objectified Draupadi and she was reduced to a mere speck of dirt who can be possessed by multiple men. She was denied a subjective position and put to a stake by Yudhisthira in the game of dice. A woman who is on her bleeding days was dragged into the court by Dushasana and despite her repeated cajoling was disrobed. It was only Krishna's divine intervention that protected her modesty. Recent feminist writers refer to the harrowing incident of disrobing as experienced by Draupadi, as an extended socio-cultural trope of contemporary societal discourse and eternalized the notion of the female body being the perpetual site of marking male hegemony. Since the integrity and dignity of a woman find a place in her broken body, its transgression through public stripping implies that her honour is undermined and she is taken as a non-individual, non-entity. In Mahabharata Draupadi's disrobing is a climactic phase of disrespecting and condemning the Pandavas. Her powerful diction and body language upset the oppressors' cunning plots for her subservience. Her retaliation lies in thwarting the whole patriarchal system of comparing the virtuosity and chastity of a woman with an immaculate body. She undermines the mythical Draupadi story and simultaneously jeopardizes the substantiality of the gender hegemonies. She challenges her repressor through defiance, ire and confidence because she has gone through several attacks on her body and spirit. She assumes the role of a feminist icon who has the guts to question and thwart the commodification of women in society. It is her feminine strength and 
integrity which becomes expressive when she comes out unscathed during the stripping episode in the "sabhaparva" of Mahabharata. Draupadi raises her voice against the inflictions on her body and mind in such a way that she redefines and reclaims her identity. She abjures the concept of women surviving as an object in his story and the male gaze, but affirms her subjectivity and claims her lost space and voice. In this context Laura Mulvey's theory of male gaze in her phenomenal work Visual Pleasure and Narrative Cinema (1975) holds true: Woman, then, stands in patriarchal culture as a signifier for the male other, bound by a symbolic order in which man can live out his fantasies and obsessions through linguistic command by imposing them on the silent image of a woman still tied to her place as the bearer of meaning, not maker of meaning (58).

Through protests, she becomes one who has the capacity to question male authority, power and dominion. By doing so Draupadi renounces the binary structures of patriarchal discourses of the "ideological state apparatuses" (Althusser) of the society, hence confuting objectification in the society and eschews her recognition as a subject, not as an object. Draupadi, unlike Sita in the Ramayana, is not a submissive object to be used, reused and discarded when no longer in use. She emerges as a strong voice that can altogether disrupt the hegemonic structures of patriarchy and give the women their legitimate dues. Preeti Chaudhary (2014) portrays Draupadi as "not a human ... a superhuman, worshipped as a cult Goddess in many temples of South India". She is firm, resolute and confident, a "proud and angry heroine of the epic Mahabharata who has remained an enigmatic woman of substance" (Chaudhary 2014:17). She is also recognized by others as the foremost feminist of Indian mythology because of her dynamism and denial of "male-dominated religious hierarchy" (Ganguli 1990).

The prominent women of the epics have remained under dark for ages in the mythical narratives and they have gained attention only in their association with their male counterparts always remaining servile to their husbands, brothers, fathers and sons. But Draupadi appears to break this stereotypical female figure by providing "the occasion for the violent transaction between men, the efficient cause of the crucial battle" (Spivak 1981). Alleyn Diesel (2002) analogizes her to Helen of Troy where she is "regarded by many men as a prize, valuable object to be competed for and squabbled over, and she becomes the central reason for internecine conflict, which brings disorder (adharma) and devastation to society" 
(Diesel 9). Draupadi's question on dharma shatters the silence of the "sabha" and throws a challenge to the conceptual norms of right and wrong decreed by kings. It was something that was unthinkable for a woman of her time and milieu. A pioneer of feminism, she contested for her rights when her incarcerated husbands had staked her in a game of dice. In the sabha where the scions of the Kuru dynasty were present, she dared to stand for herself and speak up, aloud, against injustices crowding in a patriarchal world. Not only that she was the woman who liberated her husbands from the bondage of servility by seeking their freedom from Dhritarashtra but also, she had the right attitude of a princess, a Kshatriya. In the Mahabharata she proves that no situation is insurmountable, and she never abandons her husbands, regardless of the circumstances they lead her into. Throughout the epic the true character of Draupadi emerges, displaying her subjectivity, power, and unbending will for both justice and vengeance. Through these idiosyncrasies, the figure of Draupadi has evolved to be symptomatic of women empowerment and has earned reverence from many. Not only is Draupadi a bold character, but was also a devoted wife, virtuous, spiritual and compliant to dharma and thus an iconic figure in Hindu mythology. Draupadi's distinction among other women from the epics is preponderant and well deserved; she was far ahead of her time, often found commanding her husbands to do her bidding. It is her strength and boldness to use her upright status with the right attitude and insight which made her earn a distinguished position in the history of epics. Draupadi will be remembered more as a woman who fought against all injustices crowding in a phallic world rather than one who co-habited with five husbands and conformed to their wishes.

\section{References}

Althusser, Louis. "Ideology and Ideological State Apparatuses: Notes Towards an Investigation". Lenin and Philosophy and Other Essays. Translated by Ben Brewster. Monthly Review, 1971.

Bhawalkar, Vanamala. Eminent Women in the Mahabharata. Sharada Publishing, 2002. Chaudhary, Preeti. "Frailty! Thy Name is Not Woman" with reference of Draupadi. BBSSES Vol. 5 Issue 3, 2014.

Chitra, Banerjee K. The Palace of Illusion. Pan Macmillan Ltd. 2009. 
Devi, Mahasweta. "Draupadi”. Translated by Gayatri Chakravorty Spivak. Critical Inquiry, 1981, Vol. 8, No. 2, pp. 381-402.

Diesel, Allyen. “Tales of Women's suffering: Draupadi and other Amman Goddesses as Role Models for Women”, Journal of Contemporary Religion,2002, Vol. 7, No. pp 5-20.

Ganguli, Kisari Mohan. The Mahabharata of Vyasa. Munshiram Manoharlal Publishers Pvt. Ltd. 1990.

Mulvey, Laura. Visual Pleasure and Narrative Cinema. University of Glasgow, 1975. 20.

Neelakantan, Anand. Ajaya: Roll of the Dice. Platinum Press, 2013.

Pattanaik, Devadatta. The Common Wife Jaya: An Illustrated Retelling of the Mahabharata. Penguin, 2010. 